\title{
The potential fire and explosion hazards in biomass co-firing with conventional fossil fuels based on data obtained during testing
}

\author{
Bozena Kukfisz ${ }^{1, *}$ \\ ${ }^{1}$ The Main School of Fire Service, Faculty of Fire Safety Engineering, 52/54, Slowackiego Street, 01- \\ 629 Warsaw, Poland
}

\begin{abstract}
The use of biomass, in particular in power engineering, has created new hazards for mankind and for the environment; including fire and explosion hazards. A description was provided of the use of biomass in power engineering in existing boilers fired by hard coal [110]. Literature and experimental values were outlined for selected parameters of ignitability and explosiveness of selected biomass parameters, and a comparison was presented of the ignitability and the explosiveness parameters for selected biomass dust, a mixture of coal and biomass and for coal dust (according to PN-EN 14034, PN-EN 50281-2-1:2002 and PN-EN 13821:2004). Based on an analysis of the obtained results, it was ascertained that performing analyses of explosive parameters separately, or with a share of coal and biomass, is an incorrect practice due to the fact that in literature on this subject or in the databases of Internet sources, the quoted values are purely indicative in nature and may differ from the conditions actually prevailing in the given technological process during biomass co-firing. A review of the value of the Kst explosiveness factor showed that dust of biomass mixtures may be categorised to dust with strong explosiveness parameters, and their value is higher than coal dust which is comprised within them. Consequently the testing of post-filtering dust is clearly justified.
\end{abstract}

\section{Biomass co-firing - General overview}

The development of civilisation inherently entails the growing use of electricity and thermal power. The $20^{\text {th }}$ century was a period of dynamic civilizational development for humanity, which to a large extent was possible thanks to general access to cheap energy carriers - and namely coal and first of all crude oil. On the other hand, the $21^{\text {st }}$ century is characterised by a considerable increase in demand for electric power. The basic fuel in the state industrial utility power industry is hard and brown coal. In the whole world, obtaining energy is based to a large extent on the burning processes, which primarily comprises fossil materials. Their global resources are limited, and are estimated to be sufficient for ca. 30

\footnotetext{
*Corresponding author: bkukfisz@sgsp.edu.pl
} 
years for crude oil and natural gas, and as regards hard coal - a period of approximately 200 years. Consequently, it is necessary to seek alternative energy sources and to develop profitable technologies for obtaining and processing them in order to generate electric or heating power. Electric power generation worldwide is a result of the processing of diverse types of primary energy, and the share of particular types of that energy depends on the degree of the mastering of diverse processing technologies, the economic effectiveness of processing and on the structure of energy resources in the given country. In Poland $91 \%$ of electric power is generated from hard and brown coal (the highest share in Europe). Taking into consideration conditions related to the use of renewable energy in Poland it was assumed that the basic source of renewable energy would be biomass. For this reason the role of biomass is increasing as a renewable raw material used in electric and thermal power generation and for the production of liquid and gaseous fuels. Biomass is currently the biggest source of renewable energy in Poland. It is estimated that at an annual consumption of ca. 140 million $\mathrm{Mg}$ of coal for power engineering purposes in Poland, the demand for biomass in the power industry during the forthcoming few years will grow to over 14 million $\mathrm{Mg}$ [1-4].

The use of biomass, especially in power engineering, gave rise to new hazards for man and for the environment, including fire and explosion hazard. The paper presents such hazards connected with the use of biomass, as co-firing fuel in power plants and heat and power generation plants. The definition of the co-firing of biomass with coal refers to a set of processes consisting of the burning of coal with diverse types of appropriate selected solid biofuels or products derived from their processing. This technology combines the use of renewable energy sources with the use of energy from fossil fuels $[5,6]$.

\subsection{Biomass use in CHPs}

Due to diverse legal acts adopted recently related to promoting the use of renewable energy sources (RES), many technologies are being developed to allow the energy-related use of biomass with the use of existing boilers fired by hard coal [7]. The basic way of using biomass in power systems consist of its direct burning, direct co-firing, co-firing in a hybrid-parallel system, indirect co-firing, where biomass firing takes place in the prefurnace chamber and indirect co-firing combined with earlier pyrolysis or gasification of biomass. All the presented variants may be implemented both for fluidised, stoker fired and pulverised fuel boilers. Direct combustion comprises the oxidation of biomass with the use of excess air. The generated hot exhaust gas is used for the production of hot water in heat generation plants or steam in heat and power generation plants. The firing process may be conducted in well-known and commonly used grate furnaces, drum furnaces, pulverised fuel furnaces and fluidised fuel furnaces. Direct co-firing with another fuel in Poland is primarily comprised of hard or brown coal. In this process use is made of conventional boilers, which are filled with fuel and biomass, either preliminarily mixed or separately. This co-firing way is applied in the first place in major installations. Co-firing in the hybrid - parallel system comprises burning biomass in a separate boiler and the transmission of steam generated in it to a joint system that supplies the steam turbine. The boiler that fires biomass may generate water steam with different parameters than the fuel for conventional fuel. Water steam is introduced into the turbine in an appropriate decompression degree. Indirect co-firing is combined with the earlier pyrolysis or gasification of biomass in a separate installation and then gasification products are fired in the boiler. This firing method may be called an indirect method [8-10].

Consequently, the use of biomass requires the setting up of separate infrastructure in the area of the heat and power generation plant for storing, warehousing, preliminary processing and dosing fuel to the boiler. Taking into account biological processes, as well 
as the hazard of self-ignition, it is not advisable to set up a reserve of granulated biomass for a period longer than 2-3 days of boiler operation. If it is impossible to obtain the appropriate biomass assortment, it is necessary to take into consideration the necessity of developing the fuel system infrastructure. It should primarily comprise a roofed biomass storage area, system of fire hydrants, transport devices, belt conveyors, screw-conveyor feeders, bucket feeders, biomass hopper bunker, biomass mill in the event of installation of dust burners, choppers in the case of boiler fired by chips, and an initial dryer in the event of high humidity contents in biomass [11, 12].

The burning of each type of fuel requires the usage of appropriate boiler type and specialist systems for preparing fuel and air. A correctly designed boiler should assure a sufficient time during which full fuel combustion takes place and a sufficient amount of heat should be taken over to cool the exhaust gas prior to its discharge to treatment devices [13].

Until now, the Polish utility power industry has not undertaken large scale attempts at the co-firing of waste, including municipal waste, but legal regulations concerning waste management require reducing the storage of waste in favour of other management forms. The preferred methods of waste utilisation comprise recycling and usage for the power industry [14-16].

\subsection{Determination of parameters of ignitability and explosiveness of dusts - description of research methods}

A basic impact on the assessment of explosion hazard in the firing of coal and biomass is exerted by the physical and chemical parameters of flammable dusts, the parameters of the technological process, the dimensions and types of sources of dust emissions, the sources of ignition in areas and zones of explosion hazard, the methods of primary protection consisting in removal or prevention of the formation of a flammable mixture on the area where ignition is possible, and a method of secondary protection consisting in eliminating ignition sources from the hazard area. Quite frequently, designers and investors do not have sufficient knowledge concerning the basic physical and chemical parameters of biomass and its dusts. This information is indispensable to enable proper design in the process of development or the reconstruction of power engineering facilities, as well as in the stage when the designer carries out an explosion hazard assessment. A designer, or a person developing an explosion hazard evaluation, focuses on a thorough determination of zones in the internal spaces of devices and systems, and neglects the appraisal of a hazard, including the delimitation of potential zones in external spaces. It is a priority to assure the safety of working people, and not only the safety of the process, and when a considerable amount of capital outlays is earmarked for the protection measures of devices and installations, in such a case outlays on the current removal of settled dusts are neglected. In many cases in the event of a limited supply of biomass, power plants provide and burn diverse types of biomass with different parameters, frequently not studied sufficiently, with respect to flammability and explosiveness. To determine the ignitability and explosiveness parameters of dust the following tests should be carried out comprising the determination of the following properties:

- explosiveness characteristics with the determination of maximum explosion pressure $p_{\text {max }}$ and explosiveness factor $\mathrm{K}_{\mathrm{St}}[17,18]$,

- lower explosiveness limit LEL [19],

- minimum ignition temperature of a dust cloud $\mathrm{T}_{\mathrm{CL}}[20]$,

- minimum ignition temperature of a dust layer with a thickness of $5 \mathrm{~mm} \mathrm{~T}_{5 \mathrm{~mm}}$ [20] or $12,5 \mathrm{~mm}$ according to European standard,

- minimum ignition energy of a dust cloud MIE [21], 
- lower explosion limit [LOC].

The determination of maximum explosion pressure $\mathrm{p}_{\max }$, maximum rate of explosion pressure growth $(\mathrm{dp} / \mathrm{dt})_{\max }$, and the dust constant $\mathrm{K}_{\text {ist }}$ of dust clouds is performed on measurement stands, which have to be carried out according to standards $[17,18]$. The testing comprises a series of tests to be performed in a spherical tank having an internal volume of $20 \mathrm{dm}^{3}$. In the first stage of preparations for testing, two appropriate pyrotechnical igniters are provided and bolted on electrodes situated on the cover. Once the chamber has been closed, the container is emptied vacuum to the value of -0.6 bar, and a weighed dust sample is provided in the dust container with a volume capacity of $1.2 \mathrm{dm}^{3}$. Following the closing of required valves, initiation of the system procedure in the computer, the supplementing of required data and the activation of the "trigger" (pilot/securing starting switch) the device is automatically activated. The dust container is filled with air up to the pressure of 20 bar, and next the electric valve separating the sphere from the container is opened, as a result of which dust is pumped into the sphere up to 20 $\mathrm{dm}^{3}$, and the pressure in its interior becomes regulated to match that of the atmosphere. After a delay time of $60 \mathrm{~ms}$ (in relation to dust injection and pressure levelling) the pyrotechnical igniters provided earlier in the geometrical centre of the sphere become ignited as a result of transmission of energy in the form of an electrical spark from the triggering system. If the dust and air mixture ignites, sensors of dynamic pressure record a change in pressure over time and the maximum value of pressure inside the spherical tank during testing. The one-off testing allows the determination of the rate at which pressure grows over time and the maximum value of pressure recorded during the trial. The testing of parameters $\mathrm{p}_{\max },(\mathrm{dp} / \mathrm{dt})_{\max }$ and $\mathrm{K}_{\mathrm{st}}$ are made in a similar way by placing further concentrations of dust and air in the research chamber. Those concentrations are within the sequence $\ldots: 60 ; 125 ; 250 ; 500 ; 750 ; 1000 ; 1250 ; 1500 ; \ldots \mathrm{g} / \mathrm{m}^{3}$. The testing is conducted until the time when the maximum values of the above mentioned parameters have been determined (maximum value of the parameter is confirmed by its testing performed three time for the same concentration of airborne dust). It is necessary to perform at least two tests of adjacent concentrations of the maximum value (fall of the value in the vicinity of maximum values confirms that the results have been correct). After, correcting the value of the rate of pressure growth by the volume of the spherical container $\mathrm{K}_{\mathrm{st}}$ is obtained. This index serves as a basis of the international classification of dusts with respect to their explosiveness. Adopted was a breakdown of explosive dusts into the following classes, according to the value $\mathrm{K}_{\mathrm{st}}$ (Table 1). The higher the hazard class, the bigger hazard is posed by mixtures of dust and air.

Table 1. Breakdown of explosive dusts into classes.

\begin{tabular}{|c|c|}
\hline Hazard class & $\mathbf{K}_{\mathbf{s t}}[\mathbf{m} \cdot \mathbf{b a r} / \mathbf{s}]$ \\
\hline St 1 & $<200$ \\
\hline St 2 & $200-300$ \\
\hline St 3 & $>300$ \\
\hline
\end{tabular}

The minimum ignition temperature of a dust layer $T\left[{ }^{\circ} \mathrm{C}\right]$ is the minimum ignition temperature of a dust layer, which is conducted on a research stand, in accordance with the standard PN-EN 50281-2-1:2002 [20]. The testing consists in placing a steel ring of a defined height on the surface of a plate heated up to a given temperature, the installation of a thermocouple inside the ring, and then a thorough backfilling of the ring interior by the tested dust (in an even way, without tamping). Testing is performed on the dust which has passed through the sieve with a nominal mesh size of $200 \mu \mathrm{m}$. A ring is placed on the heating plate and the thermocouple, which is provided with grooves allowing an appropriate situation of the thermocouple. Next, the plate furnace is activated, and the plate is heated up to the present temperature, and at the same time the computer is switched on 
along with software that records the temperature. Once the nominal required temperature is reached inside the ring, a dust measure is placed and the dust layer is leveller to the upper ring surface. Next the dust spilled around the ring is removed as well as its surplus, and then the testing can begin. For 30 min observations are made of the conduct of dust on a plate on which constant temperature is maintained. In compliance with the standard it is considered that ignition has taken place when glowing or combustion has been ascertained, the measured oven temperature reaches $450^{\circ} \mathrm{C}$, and at lower temperatures no ignition of dust layer is observed, the measured temperature of the dust layer has exceeded by $250^{\circ} \mathrm{C}$ the temperature of the heating plate. If in a period of $30 \mathrm{~min}$ none of the above mentioned criteria are met, measurement is performed on a fresh dust dose and the plate temperature is raised by $10^{\circ} \mathrm{C}$. The results of testing are recorded in a measurement protocol. Once the lowest temperature at which ignition takes place is achieved, the value is recorded and a temperature lower by $10^{\circ} \mathrm{C}$ is recorded than the minimum ignition temperature of a dust layer.

In the testing of the minimum ignition temperature of a dust layer in a furnace at a constant temperature, use is made of a furnace conforming to requirements of the standard [20]. Inside the oven there is a heated silica pipe (set up vertically), with an open bottom end. The pipe contains two thermocouples, one that measures the temperature of the internal oven wall, and the second one - the atmosphere of the oven. Onto the upper part of the silica pipe has been mounted dust feeder. The latter one is connected by a rubber hose to an electromagnetic pressure valve. The valve releases compressed air, which blows in the contents of the dust container to the interior of the oven. If dust becomes ignited, a discharge of flames is visible beyond the lower end of the silica pipe which may be observed in the mirror set up under the outfall of the oven of polished stainless steel. The testing is performed using dust with a mesh diameter of up to $71 \mu \mathrm{m}$. In the container ca. $0.1 \mathrm{~g}$ of dust is provided and the oven temperature is set at $500^{\circ} \mathrm{C}$. If ignition does not take place, the testing is repeated with a new sample of dust and a temperature increased by $50^{\circ} \mathrm{C}$, even up to $1000^{\circ} \mathrm{C}$. If ignition does take place, the mass of the dose and the pressure of air blown in is changed until a more intense ignition is obtained. Using the same dose and pressure as for the most intense ignition, the oven temperature is lowered by $20^{\circ} \mathrm{C}$ until the moment when ignition does take place in 10 subsequent trials (trials are also performed at the lowest evaluated temperature for diverse doses and pressure). If ignition takes place, the above procedure is repeated. If ignition has not taken place, the final temperature is recorded (reduced by $20^{\circ} \mathrm{C}$ for an oven temperature over $300{ }^{\circ} \mathrm{C}$, or reduced by $10^{\circ} \mathrm{C}$ for a temperature lower or equal to $\left.300^{\circ} \mathrm{C}\right)[6]$.

The determination of the minimum ignition energy is done on a stand which comprises a research vessel (Hartmann pipe), a high voltage electrode, movable electrode, two high voltage conductors (one each for every electrode) and a pneumatic hose supplying air to generate a dust-air mixture [21]. The control panel of the device allows setting up the delay time from $0 \mathrm{~ms}$ to $10000 \mathrm{~ms}$ and the regulation of the discharge spark energy to the value of $1 \mathrm{~mJ}, 3 \mathrm{~mJ}, 10 \mathrm{~mJ}, 30 \mathrm{~mJ}, 100 \mathrm{~mJ}, 300 \mathrm{~mJ}$ and $1000 \mathrm{~mJ}$. Pressurised air is automatically pumped into the chamber, which raises the dust forming a suspended cloud for a short time inside the Hartmann pipe. After the lapse of the delay time the pneumatic actuator triggers the movement of the right electrode, which moves toward the top of the second electrode at a distance of ca. $6 \mathrm{~mm}$. In such a case, a discharge of the condenser takes place, as a result of which a spark jumps between the electrodes. If the discharge energy is sufficient, ignition of the dust-air mixture takes place. The occurrence of an ignition or its lack thereof is recorded in the measurement record. 


\subsection{Results of the determination of dust ignitability and explosives parameters}

The explosiveness and flammability of dusts depends on the fragmentation of a given dust. According to measurement standards a sample of dust, for which determination is made, should as a rule have a fragmentation below $63 \mu \mathrm{m}$. However, in diverse technological conditions the fragmentation of dust differs, and hence causes a differentiation of real hazard. In tests for practical purposes different fragmentation is admissible, however, provided that the dust would become effectively sprayed in research equipment. The parameters of ignitability and explosiveness may be found in professional literature or in databases provided by Internet resources, such as GESTIS Dust Ex, yet it should be borne in mind that these values are merely of an indicative nature and may differ from conditions prevailing in the technological process of biomass co-firing. Given the fact that in professional literature and in the database of internet resources the values are merely informational and may differ from conditions that prevail during the technological process in biomass co-firing. Table 2 presents a comparison of the parameters of flammability and explosiveness for selected dusts of biomass, a mixture of coal and biomass and coal dust.

Table 2. Comparison of the parameters for biomass dust, mixture of coal and biomass and coal dust.

\begin{tabular}{|c|c|c|c|c|}
\hline \multicolumn{2}{|l|}{ Parameter } & \multirow{2}{*}{$\begin{array}{c}\text { Biomass dust } \\
5.9-8.4\end{array}$} & \multirow{2}{*}{$\begin{array}{c}\text { Mixture of coal and } \\
\text { biomass }\end{array}$} & \multirow{2}{*}{$\begin{array}{c}\text { Coal dust } \\
6.0-8.0 \\
\end{array}$} \\
\hline \multirow{5}{*}{$\begin{array}{l}\text { Maximum } \\
\text { explosion } \\
\text { pressure } \quad p_{\max } \\
{[\text { bar] }}\end{array}$} & & & & \\
\hline & & $4.4-8.9$ & $5.5-8.5$ & $5.6-7.4$ \\
\hline & Post-filtration dust & & $7.5 \pm 0.5$ & \\
\hline & $85 \%$ of coal $15 \%$ of straw & & $6.0 \pm 0.5$ & $7.4 \pm 0.5$ \\
\hline & $70 \%$ of coal $30 \%$ of straw & & $6.4 \pm 0.5$ & \\
\hline \multirow{5}{*}{$\begin{array}{l}\text { Explosiveness } \\
\text { ratio } \\
\mathrm{K}_{\mathrm{st}}[\mathrm{bar} / \mathrm{s}]\end{array}$} & & $9-161$ & $41-146$ & $28-135$ \\
\hline & & $5-128$ & $43-105$ & $28-87$ \\
\hline & Post-filtration dust & & $127 \pm 15$ & \\
\hline & $85 \%$ of coal, $15 \%$ of straw & & $64 \pm 13$ & $70 \pm 14$ \\
\hline & $70 \%$ of coal, $30 \%$ of straw & & $74 \pm 15$ & \\
\hline \multirow{4}{*}{$\begin{array}{l}\text { Ignition } \\
\text { temperature of } \\
\text { dust cloud } \mathrm{T}_{\mathrm{cl}} \\
{\left[{ }^{0} \mathrm{C}\right]}\end{array}$} & & $360-900$ & $450-740$ & $420-750$ \\
\hline & Post-filtration dust & & $440 \pm 10$ & \\
\hline & $85 \%$ of coal, $15 \%$ of straw & & $510 \pm 10$ & $600 \pm 10$ \\
\hline & $70 \%$ of coal, $30 \%$ of straw & & $470 \pm 10$ & \\
\hline \multirow{4}{*}{$\begin{array}{l}\text { Ignition } \\
\text { temperature of } \\
\text { dust cloud } \mathrm{T}_{5 \mathrm{~mm}} \\
{\left[{ }^{0} \mathrm{C}\right]}\end{array}$} & & $220-400>400$ & $260-400>400$ & $300-400>400$ \\
\hline & Post-filtration dust & & $290 \pm 10$ & \\
\hline & $85 \%$ of coal, $15 \%$ of straw & & $300 \pm 10$ & $380 \pm 10$ \\
\hline & $70 \%$ of coal, $30 \%$ of straw & & $300 \pm 10$ & \\
\hline \multirow{4}{*}{$\begin{array}{l}\text { Minimum } \\
\text { ignition energy } \\
\text { of a mixture of } \\
\text { dust and air } \\
{[\mathrm{mJ}]}\end{array}$} & & $\begin{array}{c}\mathrm{MIE}<3 \\
3<\mathrm{MIE}<1000 \\
\mathrm{MIE}>1000\end{array}$ & $30<\mathrm{MIE}<1000$ & MIE $>1000$ \\
\hline & Post-filtration dust & & $300<\mathrm{MIE}<1000$ & \\
\hline & $85 \%$ of coal, $15 \%$ of straw & & MIE $>1000$ & MIE $>1000$ \\
\hline & $70 \%$ of coal, $30 \%$ of straw & & $30<\mathrm{MIE}<100$ & \\
\hline
\end{tabular}

\subsection{Analysis of results of the determination of dust ignitability and explosiveness parameters}

The most reliable method adopted to determine the parameters of ignitability and explosiveness is the collection of a specimen of dust from the appraised technology and its experimental determination. Good practice in preventing explosions is to test post-filter dusts. On the basis of the attached listings of ignitability and explosiveness parameters presented in Table 2, a presumption may be made that the dust of a mixture of coal and biomass is much more dangerous than that of coal dust or biomass dust. The maximum 
explosion pressure of biomass dusts and their mixtures is within the range from 5.5 bar to over 8.0 bar. The "Barbara" Experimental Mine has introduced an additional classification which comprises only coal dusts. This classification divided coal dusts into three main groups:

- weakly explosive dust with Kst $<70 \mathrm{mbar} / \mathrm{s}$,

- average explosive dust with Kst from $71 \mathrm{mbar} / \mathrm{s}$ to $110 \mathrm{mbar} / \mathrm{s}$,

- highly explosive dust with Kst $>110 \mathrm{mbar} / \mathrm{s}$.

An analysis of the value of the explosiveness factor Kst, indicates that the dusts of biomass mixtures may be categorised as strongly explosive dusts, and so their value is higher than that of coal dust which is comprised by it.

During the testing it was noticed that the value of $p_{\max }$ determined for mixtures of biomass dust and coal dust was higher than the value defined for particular dusts separately. This effect intensifies the explosion hazard. This phenomenon has been recorded during the determination of the maximum values of explosion pressure of mixtures of biomass dusts and hard coal dust at a weight ratio of 50:50. A most likely cause of this dependence arises from differences in the contents of volatile parts in biomass samples, as well as differences in the course of the process of thermal decomposition and the explosion visible on explosion pressure diagrams in the function of time.

The paper pointed to the significant differences in explosiveness parameters that may be found between coal dust and biomass dusts. However, these changes are not always unambiguous, e.g. the addition of biomass causes an increase in the value of MITL (arising from the mechanism of heat transmission between particles of biomass and carbon dust) and concurrent decrease in the value of MTCD. The minimum ignition temperature of a dust layer and ignition temperature of a dust layer are similar, and limit values of temperatures are practically identical. The value of the ignition temperature of a cloud of dust mixtures are within the range from $400^{\circ} \mathrm{C}$ to $500^{\circ} \mathrm{C}$.

It may clearly be concluded that the use of biomass in co-firing has to be preceded by an in-depth analysis both of technical aspects, as well as aspects connected with fire and explosion safety. Appropriate knowledge concerning each type of biomass, specialist know-how and good engineering practice are the sole guarantors of safety in the process of biomass co-firing.

Biomass has been in use worldwide as flammable material for years now. Until now, numerous research works have been carried out, the results of which, owing to the differing elementary composition and different research methods, are not easy to interpret in an unambiguous way. Available literature sources confirmed the insufficient knowledge concerning biomass from the viewpoint of explosion protection methods. If correctly interpreted, results of the testing of dust explosiveness and ignitability may be used for an evaluation of the explosion and fire hazard in premises and in installations where those dusts are present, and to formulate detailed requirements concerning the application of protective devices and systems.

\section{References}

1. P. McKendry, Bioresource Technology, 83, 37-46, (2002).

2. M. Zajemska, D. Musiał, Problemy Inżynierii Rolniczej, 4, 107-118, (2013).

3. W. Wyszkowski, Instalacje biomasy $\mathrm{w}$ elektrowniach $\mathrm{w}$ praktyce, Ochrona Przeciwpożarowa, 1, (2014).

4. J. Zuwała, Energetyka, Problemy Energetyki i Gospodarki Paliwowo-Energetycznej, 2, $108-114$, (2010). 
5. L. Szecówka Ekologiczne efekty energetyczne wykorzystania biopaliw, (Wydawnictwo Politechniki Częstochowskiej, Częstochowa 2009).

6. W. Rybak Spalanie $i$ wspótspalanie biopaliw statych, (Oficyna Wydawnicza Politechniki Wrocławskiej, Wrocław 2006).

7. M. Ściążko, J. Zuwała, M. Pronobis, Wspótspalanie biomasy i paliw alternatywnych w energetyce (Instytut Chemicznej Przeróbki Węgla i Politechniki Śląskiej, Zabrze 2007).

8. J. M. Ebeling, B. M. Jenkins, Transactions of the American Society of Agricultural and Biological Engineers, 23, 898-902, (1985).

9. M. Sami, K. Annamalai, M. Wooldrige, Progress in Energy and Combustion Science, 27, 171-214, (2001).

10. R. K. Eckhoff, Journal of Loss Prevention in the Process Industries, 18, 225-237, (2005).

11. J. Gummer, G. A. Lunn, Journal of Loss Prevention in the Process Industries, 16, 2732, (2003).

12. K. R. G. Hein, J. M. Bemtgen, Fuel Processing Technology, 54, 158-169, (1998).

13. A. Kuczaj, Budownictwo i Inżynieria Środowiska, 1, 205-214, (2010).

14. C. H., Medina, H. N. Phylaktou, H. Sattar, G. E. Andrews., B. M. Gibbs, Biomass and Bioenergy, 53, 95-104, (2013).

15. C. H., Medina, B. MacCoitir, H. Sattar, D. JF Slatter, H. N. Phylaktou, G. E. Andrews., B. M. Gibbs, Fuel, 151, 91-101, (2015)

16. Ptak S., Analiza zagrożeń wybuchowych zwiąanych ze wspótspalaniem biomasy $i$ wegla, (Rozprawa Doktorska, 2016).

17. PN-EN 14034-1+A1:2011 Determination of explosion characteristics of dust clouds Part 1: Determination of the maximum explosion pressure $\mathrm{p}_{\max }$ of dust clouds .

18. PN-EN 14034-2+A1:2011 Determination of explosion characteristics of dust clouds Part 2: Determination of the maximum rate of explosion pressure rise. $(\mathrm{dp} / \mathrm{dt})_{\max }$ of the dust clouds

19. PN-EN 14034-3+A1:2011 Determination of explosion characteristics of dust clouds Part 3: Determination of the lower explosion limit LEL of dust clouds

20. PN-EN 50281-2-1:2002 Electrical appliances for usage in the presence of flammable dusts. Part 2-1 Testing methods - Determinaion methods of minimum dust ignition temperature

21. PN-EN 13821:2004 Potentially Explosive Atmospheres - Explosion Prevention and Protection - Determination of Minimum Ignition Energy of Dust/Air Mixtures 